\title{
Bladder cancer in the EMPA-REG OUTCOME trial
}

\author{
Sven Kohler ${ }^{1} \cdot$ Jisoo Lee $^{1} \cdot$ Jyothis T. George ${ }^{1} \cdot$ Silvio E. Inzucchi ${ }^{2} \cdot$ Bernard Zinman $^{3}$
}

Received: 21 August 2017 / Accepted: 22 August 2017 /Published online: 14 September 2017

(C) The Author(s) 2017. This article is an open access publication

Keywords Bladder cancer · Cancer · Empagliflozin · SGLT2 inhibitors $\cdot$ Type 2 diabetes

\section{Abbreviation \\ SGLT2 Sodium-glucose cotransporter 2}

To the Editor: We read with interest the recently published article in Diabetologia by Tang et al on the risk of cancer in patients with type 2 diabetes treated with sodium-glucose cotransporter 2 (SGLT2) inhibitors [1]. We agree with their conclusion that treatment with SGLT2 inhibitors is not associated with a significantly increased risk of cancer. In their analysis of specific cancer types, the authors suggest that SGLT2 inhibitors may be associated with an increased risk of bladder cancer. With respect to empagliflozin, the authors report that the cardiovascular outcomes trial, EMPA-REG OUTCOME, conducted in individuals with type 2 diabetes and established cardiovascular disease, contributed over $50 \%$ of individuals and events to their analysis of bladder cancer. We would like to draw attention to data from this trial

Sven Kohler

sven.kohler@boehringer-ingelheim.com

1 Boehringer Ingelheim Pharma GmbH \& Co. KG, Binger Strasse 173, 55216 Ingelheim, Germany

2 Section of Endocrinology, Yale University School of Medicine, New Haven, CT, USA

3 Lunenfeld-Tanenbaum Research Institute, Mount Sinai Hospital, University of Toronto, Toronto, Canada that were not considered by the authors, which (except for the data on the events reported up to 7 days after the last intake of study drug) were included in documents submitted to the US Food and Drug Administration [2]. In the EMPA-REG OUTCOME trial, cases of bladder cancer were identified from adverse events coded using the following preferred terms in the Medical Dictionary for Regulatory Activities (MedDRA): 'bladder cancer'; 'bladder cancer recurrent'; 'bladder cancer transitional cell carcinoma'; and 'transitional cell carcinoma'. Transitional cell carcinoma accounts for over $90 \%$ of all bladder cancers [3]. Documentation relating to events coded as transitional cell carcinoma was medically reviewed and cases confirmed. In an on-treatment analysis based on events reported from the first intake of study drug up to 7 days after the last intake, four transitional cell carcinoma cases were located in the bladder (three in the placebo group, one in the empagliflozin $10 \mathrm{mg}$ group) and one was located in the ureter (in the empagliflozin $25 \mathrm{mg}$ group). In an intent-to-treat analysis (based on events reported from the first intake of study drug up to trial termination in patients treated with $\geq 1$ dose of study drug), bladder cancer was reported in $5 / 2333$ patients $(0.2 \%)$ in the placebo group, $3 / 2345$ patients $(0.1 \%)$ in the empagliflozin $10 \mathrm{mg}$ group and $9 / 2342$ patients $(0.4 \%)$ in the empagliflozin $25 \mathrm{mg}$ group (Table 1).

To elucidate the potential association between a substance and carcinogenesis, length of exposure needs to be considered. We undertook an additional analysis of patients with at least 6 months' drug exposure. Bladder cancer with an onset after 6 months' cumulative exposure to study drug was reported in $4 / 2187$ patients $(0.2 \%)$ in the placebo group, $3 / 2216$ patients $(0.1 \%)$ in the empagliflozin $10 \mathrm{mg}$ group, and 7/2190 patients $(0.3 \%)$ in the empagliflozin $25 \mathrm{mg}$ group (Table 1 ).

With the number of events being so small, a few additional cases can make a difference to the conclusions drawn. Based 
Table 1 Bladder cancer events in the EMPA-REG OUTCOME trial

\begin{tabular}{|c|c|c|c|c|}
\hline Events & Placebo & $\begin{array}{l}\text { Empagliflozin } \\
10 \mathrm{mg}\end{array}$ & $\begin{array}{l}\text { Empagliflozin } \\
25 \mathrm{mg}\end{array}$ & $\begin{array}{l}\text { Empagliflozin } \\
\text { pooled }\end{array}$ \\
\hline $\begin{array}{l}\text { Events from first intake of study drug up to } 7 \text { days after the } \\
\text { last intake of study drug }\end{array}$ & $n=2333$ & $n=2345$ & $n=2342$ & $n=4687$ \\
\hline Bladder cancer & $3(0.1)$ & $3(0.1)$ & $8(0.3)$ & $11(0.2)$ \\
\hline Bladder cancer & 0 & $1(<0.1)$ & $5(0.2)$ & $6(0.1)$ \\
\hline Bladder cancer recurrent & 0 & 0 & $1(<0.1)$ & $1(<0.1)$ \\
\hline Bladder cancer transitional cell carcinoma & 0 & $1(<0.1)$ & $1(<0.1)$ & $2(<0.1)$ \\
\hline Transitional cell carcinoma & $3(0.1)$ & $1(<0.1)$ & $1(<0.1)$ & $2(<0.1)$ \\
\hline $\begin{array}{l}\text { Events from first intake of study drug up to trial } \\
\text { termination }\end{array}$ & $n=2333$ & $n=2345$ & $n=2342$ & $n=4687$ \\
\hline Bladder cancer & $5(0.2)$ & $3(0.1)$ & $9(0.4)$ & $12(0.3)$ \\
\hline Bladder cancer & $1(<0.1)$ & $1(<0.1)$ & $6(0.3)$ & $7(0.1)$ \\
\hline Bladder cancer recurrent & 0 & 0 & $1(<0.1)$ & $1(<0.1)$ \\
\hline Bladder cancer transitional cell carcinoma & 0 & $1(<0.1)$ & $1(<0.1)$ & $2(<0.1)$ \\
\hline Transitional cell carcinoma & $4(0.1)$ & $1(<0.1)$ & $1(<0.1)$ & $2(<0.1)$ \\
\hline $\begin{array}{l}\text { Events with onset after } 6 \text { months' cumulative exposure up } \\
\text { to trial termination }\end{array}$ & $n=2187$ & $n=2216$ & $n=2190$ & $n=4406$ \\
\hline Bladder cancer & $4(0.2)$ & $3(0.1)$ & $7(0.3)$ & $10(0.2)$ \\
\hline Bladder cancer & $1(<0.1)$ & $1(<0.1)$ & $5(0.2)$ & $6(0.1)$ \\
\hline Bladder cancer recurrent & 0 & 0 & 0 & 0 \\
\hline Bladder cancer transitional cell carcinoma & 0 & $1(<0.1)$ & $1(<0.1)$ & $2(<0.1)$ \\
\hline Transitional cell carcinoma & $3(0.1)$ & $1(<0.1)$ & $1(<0.1)$ & $2(<0.1)$ \\
\hline
\end{tabular}

Data are $n(\%)$ with events in patients treated with $\geq 1$ dose of study drug

Bladder cancer events were identified based on Medical Dictionary for Regulatory Activities (MedDRA) preferred terms (plus medical review of cases for events coded as transitional cell carcinoma)

on the totality of the data, no imbalance in bladder cancer cases between empagliflozin and placebo were observed in the EMPA-REG OUTCOME trial.

Acknowledgements Medical writing assistance, supported financially by Boehringer Ingelheim, was provided by $\mathrm{E}$. $\mathrm{Ng}$ of FleishmanHillard Fishburn, London, UK during the preparation of this letter. The authors were fully responsible for all content and editorial decisions, were involved at all stages of development and have approved the final version.

Funding The EMPA-REG OUTCOME trial was funded by the Boehringer Ingelheim \& Eli Lilly and Company Diabetes Alliance. One of the funders of the study (Boehringer Ingelheim) had a role in study design, data collection, data analysis, data interpretation, and writing of the report. The other funder (Eli Lilly and Company) had no role in study design, data collection, data analysis, data interpretation, or writing of the report. All authors had full access to all the data in the study and had final responsibility for the decision to submit for publication.

Duality of interest SK, JL and JTG are employees of Boehringer Ingelheim. SI has consulted for Boehringer Ingelheim, AstraZeneca, Merck \& Co, Intarcia Therapeutics, Inc., Lexicon Pharmaceuticals, Janssen, Sanofi, Novo Nordisk and VTV Therapeutics. BZ has received research grants from Boehringer Ingelheim, AstraZeneca and Novo Nordisk, honoraria from Janssen, Sanofi, Eli Lilly and Company, Boehringer Ingelheim, Novo Nordisk and Merck.
Contribution statement All authors contributed to the interpretation of data and were responsible for development of this work and revising it critically for important intellectual content. All authors approved the final version to be published.

Open Access This article is distributed under the terms of the Creative Commons Attribution 4.0 International License (http:// creativecommons.org/licenses/by/4.0/), which permits unrestricted use, distribution, and reproduction in any medium, provided you give appropriate credit to the original author(s) and the source, provide a link to the Creative Commons license, and indicate if changes were made.

\section{References}

1. Tang H, Dai Q, Shi W, Zhai S, Song Y, Han J (2017) SGLT2 inhibitors and risk of cancer in type 2 diabetes: a systematic review and meta-analysis of randomised controlled trials. Diabetologia. https:// doi.org/10.1007/s00125-017-4370-8

2. Boehringer Ingelheim (2016) Endocrinologic and metabolic drugs advisory committee briefing document. EMPA-REG OUTCOME® Trial. Available from www.fda.gov/downloads/ AdvisoryCommittees/CommitteesMeetingMaterials/Drugs/ EndocrinologicandMetabolicDrugs AdvisoryCommittee/ UCM508423.pdf. Accessed 28 July 2017

3. Griffiths TRL (2013) Current perspectives in bladder cancer management. Int J Clin Pract 65:435-448 